\title{
The Potential Role of Intrathecal Nefopam in the Management of Neuropathic Pain
}

Department of Student Research Committee, *Department of Anesthesiology, Jahrom University of Medical Sciences, Jahrom, Iran

Mohamed Amin Ghobadifar, and Navid Kalani*

\section{LETTERS TO EDITORS}

We have read with curiosity a recently published article in The Korean Journal of Pain by Kim and Abdi [1], entitled "Rediscovery of nefopam for the treatment of neuropathic pain". The authors skillfully reviewed the literature on nefopam's clinical applications, its mechanisms of action, associated adverse reactions, and they offered future directions for research. The present review is a helpful article that highlights the following recently detected dual-analgesic mechanisms of action: a) the prevention of long-term potentiation mediated by N-Methyl-D-aspartic acid (NMDA) from the inhibition of voltage-sensitive sodium channels such as carbamazepine or a blockade of calcium influx similar to that by gabapentinoid anticonvulsants; and b) decreasing pain modulation by means of triple neurotransmitter reuptake inhibition, like antidepressants, enabling nefopam to be used as a therapeutic agent for treating neuropathic pain. The authors are to be congratulated for their focus on the potential role of intrathecal nefopam as part of the management strategy for neuropathic pain according to the results gleaned from the following studies:

Nefopam is a cyclic analog of orphenadrine, though its pharmacological properties differ from those of anti-inflammatory drugs and opioids. Previous animal experiments demonstrated the antinociceptive effects of nefopam on inflammatory, incisional, and thermal pain. The antinociceptive effects of nefopam on neuropathic pain have been reported by several studies [2,3]. Additionally, the central nervous system is the site of action of nefopam, including the spinal cord. The findings of some studies suggest that nefopam reduces neuropathic pain by means of spinal nerve ligation at the spinal level $[3,4]$. Recently, the role of the $5-\mathrm{HT}_{7}$ (5-hydroxytryptamine 7 ) receptor has been highlighted in nociceptive modulation. Intrathecal and intraperitoneal $5-\mathrm{HT}_{7}$ receptor agonists decrease diabetic- and nerve-injury-deduced neuropathic pain [5]. Accordingly, the antinociceptive action of nefopam may be exerted in the spinal cord through the $5-\mathrm{HT}_{7}$ receptor. A recent animal experiment by Dam et al. [6] revealed that $5-$ HT synthesis is decreased in the spinal cord during neuropathic pain. In contrast, the synthesis of 5-HT during neuropathic pain is stimulated by nefopam. Consequently, through the activation of the $5-\mathrm{HT}_{7}$ receptor at the spinal cord, nefopam reduces neuropathic pain.

As is obvious from the above discussion, intrathecal nefopam may play a significant role in the management

Received April 22, 2014. Accepted May 10, 2014.

Correspondence to: Mohamed Amin Ghobadifar

Department of Student Research Committee, Medicine School, Jahrom University of Medical Sciences, Motahari Avenue, Jahrom, Iran Tel: +98-936-620-8078, Fax: +98-711-636-13-86, E-mail: amin_m505@yahoo.com

(c) This is an open-access article distributed under the terms of the Creative Commons Attribution Non-Commercial License (http:// creativecommons.org/licenses/by-nc/3.0/), which permits unrestricted non-commercial use, distribution, and reproduction in any medium, provided the original work is properly cited.

Copyright (c) The Korean Pain Society, 2014 
of neuropathic pain. Thus, human studies are required for a deeper understanding of this topic.

\section{REFERENCES}

1. Kim KH, Abdi S. Rediscovery of nefopam for the treatment of neuropathic pain. Korean J Pain 2014; 27: 103-11.

2. Cho SY, Park AR, Yoon MH, Lee HG, Kim WM, Choi Jl. Antinociceptive effect of intrathecal nefopam and interaction with morphine in formalin-induced pain of rats. Korean $\mathrm{J}$ Pain 2013; 26: 14-20.

3. Saghaei E, Moini Zanjani T, Sabetkasaei M, Naseri K. Enhancement of antinociception by co-administrations of nefopam, morphine, and nimesulide in a rat model of neuropathic pain. Korean J Pain 2012; 25: 7-15.

4. Biella GE, Groppetti A, Novelli A, Fernández-Sánchez MT, Manfredi B, Sotgiu ML. Neuronal sensitization and its behavioral correlates in a rat model of neuropathy are prevented by a cyclic analog of orphenadrine. J Neurotrauma 2003; 20: 593-601.

5. Ulugol A, Oltulu C, Gunduz O, Citak C, Carrara R, Shaqaqi $M R$, et al. 5-HT7 receptor activation attenuates thermal hyperalgesia in streptozocin-induced diabetic mice. Pharmacol Biochem Behav 2012; 102: 344-8.

6. Dam LJ, Hai L, Ha YM. Role of the $5-H T(7)$ receptor in the effects of intrathecal nefopam in neuropathic pain in rats. Neurosci Lett 2014; 566: 50-4. 